\title{
Care Facilitator Cart: a product technology built with nursing professionals
}

\author{
Carro Facilitador do Cuidado: tecnologia de produto construída com profissionais de enfermagem \\ Carro Facilitador de Atención: tecnología de producto construida con profesionales de enfermería
}

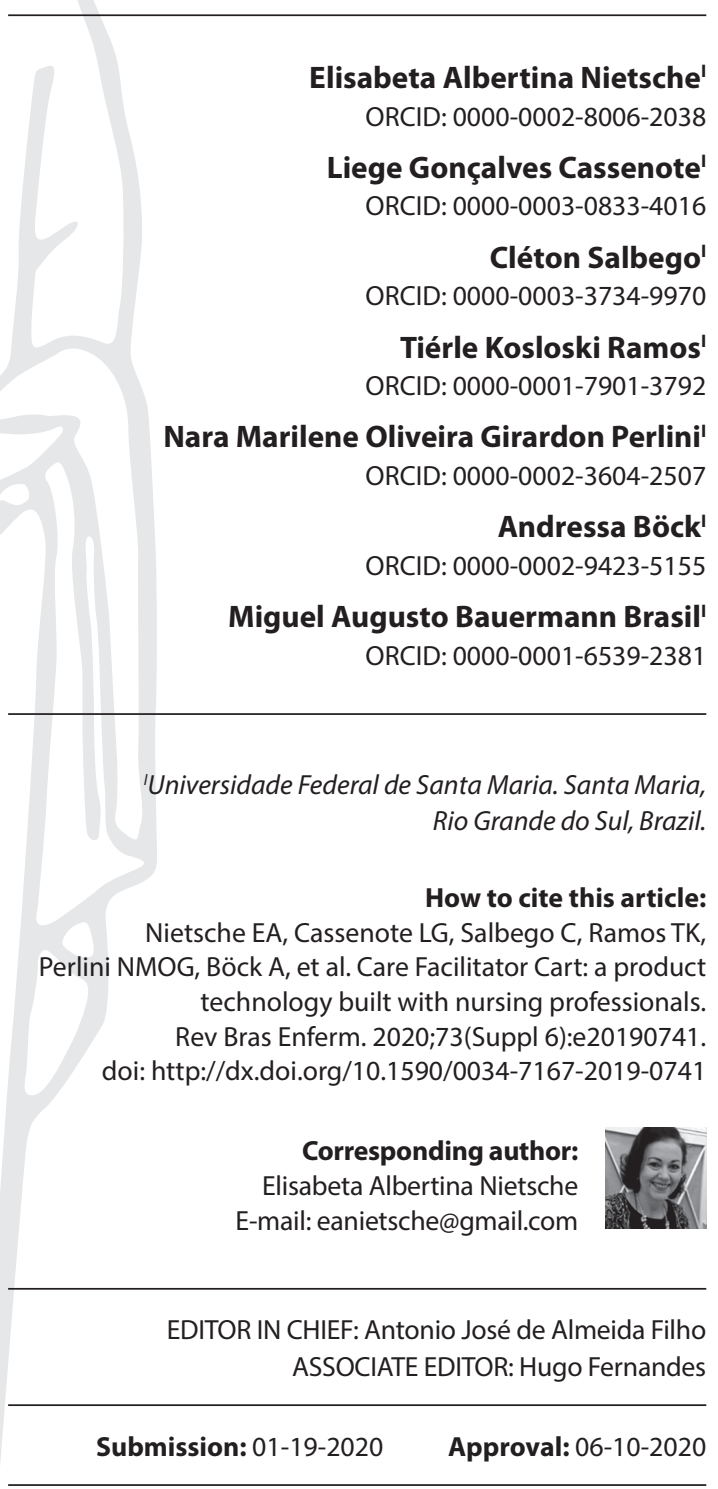

\begin{abstract}
Objectives: to describe a product technology building (Care Facilitator Cart) with nursing professionals working in surgical clinic and medical clinic at a university hospital in Rio Grande do Sul. Methods: a qualitative, methodological research guided by the Business Model Canvas, with 52 nursing professionals, through non-participant observation and brainstorming, carried out from April to October 2016. The records were analyzed through content analysis. Results: the product was built with two floors, a retractable table, a removable compartment for disposal and separation of infectious, recyclable and sharps waste, lid opening by a sensor, among others. Final Considerations: the invention unleashes possibilities to be an innovative instrument aimed at performing safe care in hospital institutions, with a view to reducing professional wear, rework, infection control, and effectiveness of procedures and techniques. Descriptors: Technological Development; Products Technology; Nurse Practitioners; Nursing Care; Hospital Care.
\end{abstract}

\section{RESUMO}

Objetivos: descrever a construção de uma tecnologia de produto (Carro Facilitador do Cuidado), com profissionais de enfermagem que atuam na clínica cirúrgica e clínica médica de um hospital universitário do Rio Grande do Sul. Métodos: pesquisa metodológica, qualitativa, norteada pelos Business Model Canvas, com 52 profissionais de enfermagem, por meio de observação não participante e brainstorming, realizadas no período de abril a outubro de 2016. Os registros foram analisados por meio da análise de conteúdo. Resultados: o produto foi construído com dois andares, uma mesa retrátil, um compartimento removível de descarte e separação de resíduos infectante, reciclável e perfurocortante, abertura das tampas das lixeiras por sensor, dentre outros. Considerações Finais: a invenção desprende possibilidades para ser um instrumento inovador voltado ao desempenho de uma assistência segura em instituições hospitalares, com vistas à redução do desgaste profissional, retrabalho, controle de infecções e, efetividade de procedimentos e técnicas.

Descritores: Desenvolvimento Tecnológico; Tecnologia de Produtos; Profissionais de Enfermagem; Cuidados de Enfermagem; Assistência Hospitalar.

\section{RESUMEN}

Objetivos: describir la construcción de una tecnología de producto (Carro Facilitador de Atención), con profesionales de enfermería que trabajan en la clínica quirúrgica y clínica médica de un hospital universitario en Rio Grande do Sul. Métodos: investigación cualitativa, metodológica, guiada por Business Model Canvas, con 52 profesionales de enfermería, a través de observación no participativa y lluvia de ideas, se llevó a cabo de abril a octubre de 2016. Los registros se analizaron mediante análisis de contenido. Resultados: el producto fue construido con dos pisos, una mesa retráctil, un compartimento removible para la eliminación y separación de desechos infecciosos, reciclables y cortantes, apertura de las cubiertas de basura por sensor, entre otros. Consideraciones Finales: la invención desata posibilidades de ser un instrumento innovador dirigido a la prestación de atención segura en instituciones hospitalarias, con el fin de reducir el desgaste profesional, el reprocesamiento, el control de infecciones y la efectividad de los procedimientos y técnicas.

Descriptores: Desarrollo Tecnológico; Tecnología de Productos; Enfermeras Practicantes; Atención de Enfermería; Atención Hospitalaria. 


\section{INTRODUCTION}

(Re)building constantly preventive focus actions, especially with regard to hospital infection control, has been a priority for health institutions. Statistics indicate that about 1.7 million nosocomial infections ( $\mathrm{NI}$ ) are directly associated with the development of care practices; and, of these, approximately 100,000 cases die. Such data refer to the need to formulate strategies and plan the health work process ${ }^{(1)}$.

At hospitals, the working hours of nursing professionals have an expressive period and assistance is focused on task fulfillment, which leads professionals to act, often, in a mechanized way. Trays are perceived with sterile material resources for performing clean and/or contaminated dressings, removal of surgical points and bladder catheterization, residues from the procedures often arranged on the patients' beds. Thus, spread of infections is favored, considering lack of time, in the midst of intense demands, for hygiene, correct disposal and storage of these materials.

Despite much knowledge produced on hospital infection prevention and control actions, there is still a large gap between practice and recommendations ${ }^{(2)}$. Institutions should review the skills of their professionals, implementing strategies to effectively achieve the excellence of care ${ }^{(3-4)}$.

Nursing over the years has been looking for different ways to qualify care. It is possible to identify advanced technological resources in hospitals that contribute significantly to the work process. Most of the product technologies, such as computerization and machines, are more prominent ${ }^{(5-6)}$.

Currently, nursing has stood out in academic circles in producing technologies in different contexts. Thinking about technology means expanding building and validation of technological products and processes that give a new meaning to nursing professional praxis. Thus, technology development must be based on the daily lives of nursing professionals and continuous assessment of service needs, so that the construct is effectively viable and applicable to course praxis ${ }^{(5)}$.

The search to develop the technological product on screen aimed to promote nursing professional performance improvement in relation to storage, handling and flow of materials and waste resulting from care procedures in hospitalization units. A technology aimed at assisting in transportation and proper organization of materials can assist in reducing the rates of nosocomial infection resulting from inappropriate practices, directly reflecting on patient safety. Therefore, building a product technology, in the form of a prototype, can assist in health promotion and facilitate nursing professional care.

The product built was supported by a relational and progressive process; valued the professionals' experience, their way and work context; aimed to insert in nursing practice a technology planned under a critical, reflective, autonomous, and enhancing thinking of professionals in the face of their work universe ${ }^{(6)}$. Thus, considering the demands and procedural diversity of the units studied, the following questions emerged: how to build a Care Facilitator Cart (CFC) based on the demand of nursing professionals who work in a medical and surgical clinic at a university hospital? Thus, the features of a CFC were enhanced, adding innovative characteristics for storage, handling and correct flow of waste resulting from care procedures in hospitals, justifying the relevance of the theme of this study.

\section{OBJECTIVES}

To describe a product technology building (Care Facilitator Cart) with nursing professionals working in surgical clinic and medical clinic at a university hospital in RS.

\section{METHODS}

\section{Ethical aspects}

The Research Ethics Committee of a federal university of Rio Grande do Sul State approved the study. The requirements contained in Resolution 466/12 of the Brazilian National Health Council (Conselho Nacional de Saúde) were respected. All participants signed the Informed Consent Form. To guarantee confidentiality and anonymity, capital letters were used, namely: O (observation), MC (medical clinic), SC (surgical clinic), and NP (nursing professional), followed by the numerical identification corresponding to the order in which it was performed collection (MCO 1, SCO 1, NP 1...).

\section{Type of study}

This is a methodological and qualitative research guided by the Business Model Canvas (BMC) precepts, which comprises carrying out nine stages, including: key partners, key activities, key resources, value offer, relationship, channels, customer segment, cost structure, and revenue sources ${ }^{(7-8)}$.

The BMC contributes to collective building from the design of the project to the performance of final versions of certain proposals. It is perceived as a visual map that promotes direction on the path to be taken by the entrepreneur. This methodology promotes active integration of ideas in building nine punctuated elements, thus enhancing visual issue so that ideas, solutions and actions are pointed out for each item in the model ${ }^{(7)}$. Applying this model facilitated consistent structuring of the projected construction object. Such model enabled divergence and convergence of the participants' opinions to a common understanding through the exercise and continuous study of the pre-established fundamental items to guide the proposal. Thus, it generated consistent indicators for technological innovation.

\section{Setting and participants of the study}

This study was carried out in the medical and surgical clinic units at a university hospital in the State of Rio Grande do Sul. A total of 118 nursing professionals located in the two units have been identified. Nurses, technicians, or nursing assistants, with a minimum experience of six months in the unit studied were included in the study. Professionals on vacation, ill, on maternity leave or any other type of leave from activities during the period of data collection were excluded. From this system, the final sample was composed of 52 participants. 


\section{Collection and organization of data}

Data collection took place from April to October 2016 by using non-participant observation and brainstorming techniques integrated with BMC. The classic brainstorming technique instigates creativity and improvement of proposals related to innovation, providing opportunities for integration and consonance of ideas in a group ${ }^{(9)}$.

Non-participant observation made it possible to know the daily practices of professionals and the relevant facts capable of influencing the subjectivity to build the technological product under study, making knowledge, the service dynamics, and its features more complete and enriching. For the record, a dense description of the observations was made in a field diary, accounting for 85 observational hours. The observations were made in different shifts; therefore, they depended on the participants' work schedules. The observation hours performed in each unit varied by approximately 40 hours. The script that guided the observations comprised product technologies used in the work of nursing professionals; situations involving "improvisation" in nursing work; what nursing professionals use to take the materials they use in care; how they organize themselves to carry out the procedures involved in care; and the description of weaknesses regarding preventing NI.

Concomitantly with the observations, meetings were held with the professionals, aiming to raise reflections for collective building of the prototype elements. Twelve meetings were held, six in each unit (two in the morning, two in the afternoon, two in the evening), totaling approximately one and a half hours each.

In the first meeting, there were agreements, exchange of knowledge regarding the BMC methodology. The CFC's initial structure was presented (Figure 1). The CFC consisted of two floors; four wheels made of silicone material; two drawers with tilting opening on the side where professionals would push the product; floor below with open sides; front side of the cart with two separate compartments for waste bins with lids with sensor opening. As for the prototype size, the initial dimensions had not been pre-established, in order to define together with the research participants. Features were planned so that the proposal made it possible to promote an environment without noise; avoid the work of nursing to dispose of infectious/contaminated waste with recyclable waste; and reduce the occurrence of cross-transmission of microorganisms using trays and materials in common use in the units.

Also, a panel showing the structural features suggested for the CFC was exposed; in which it was agreed to use post-it notes to complete the panel, in order to record contributions from participants (blue in the morning shifts, yellow in the afternoon shifts, and pink in the night shifts). Subsequently, they were invited to provide suggestions and ideas to be described in post-it notes and pasted on the panel (Figure 1). After this meeting, in each unit and shift, the researcher carried out a preliminary analysis of records in order to list the most prominent structural features among the participants.

The second meeting provided an opportunity to resume the contributions and knowledge that emerged, aiming at collective reassessment of the technological product's guiding design, described in the guiding panel. It was conducted by: (1) grouping of structural features that emerged in the first meeting through post-it notes with specific colors for each subgroup; (2) choice/refinement and joining of ideas. Each subgroup gave its opinion regarding the initial proposal maintenance (guiding design), adding or removing features; (3) after a collective analysis of the prototype features, a secondary panel (containing only the CFC guiding model) was organized with data validated by the participants, containing the following caption: green post-it note referring to the elements included in the CFC; orange post-it note regarding the elements excluded from the CFC; and purple post-it note regarding important elements suggested by the researchers during brainstorming, based on current legislation

\section{Organization and analysis of data}

Data were treated based on thematic content analysis, being operationalized from pre-analysis and material exploration. Such steps occurred through readings and organization of the findings in order to identify the units of meaning that responded to the object under study, meeting the following criteria: exhaustiveness, representativeness, homogeneity, pertinence, and exclusivity. Finally, there was treatment and interpretation of data, based on specific literature of the subject, which allowed building an analytical category. This was outlined by crossing the results obtained from non-participant observation and brainstorming. Crossover of information occurred initially through the identification of registration units and context of documents. Subsequently, the extracts were grouped by similarity of meaning to the study phenomenon.

\begin{tabular}{|c|c|c|c|}
\hline \multirow{2}{*}{$\begin{array}{l}\text { Table } 1 \\
\text { 1. Do you believe } \\
\text { that a Care } \\
\text { Facilitator Cart } \\
\text { can influence } \\
\text { the prevention } \\
\text { of nosocomial } \\
\text { infection? Why? }\end{array}$} & \multicolumn{2}{|c|}{$\begin{array}{l}\text { 1. PRODUCT: } \\
\text { CARE FACILITATOR CART }\end{array}$} & \\
\hline & $\begin{array}{l}\text { 2. What features for } \\
\text { a Care Facilitator } \\
\text { Cart would help in } \\
\text { your work? }\end{array}$ & $\begin{array}{l}\text { 3. What size do } \\
\text { you think would } \\
\text { be ideal for this } \\
\text { Care Facilitator } \\
\text { Cart? }\end{array}$ & $\begin{array}{l}\text { 4. What benefits } \\
\text { could this product } \\
\text { provide for care? }\end{array}$ \\
\hline $\begin{array}{l}\text { 5. Regarding the } \\
\text { guiding model for } \\
\text { the Care Facilitator } \\
\text { Cart, what would } \\
\text { you add? Why? }\end{array}$ & $\begin{array}{l}\text { 6. Regarding the } \\
\text { guiding model for } \\
\text { the Care Facilitator } \\
\text { Cart, what would } \\
\text { you remove? Why? }\end{array}$ & $\begin{array}{l}\text { 7. Do you suggest } \\
\text { another name } \\
\text { for the "Care } \\
\text { Facilitator Cart"? }\end{array}$ & GUIDING MODEL \\
\hline
\end{tabular}

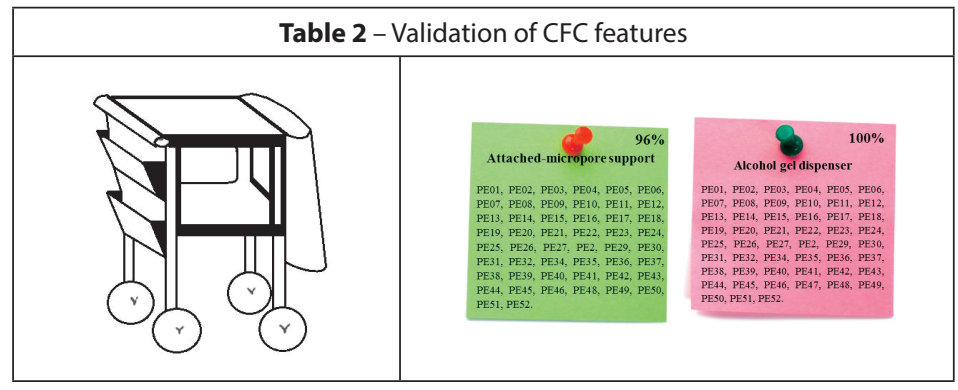

Figure 1 - Panel with triggering-questions used during brainstorming, Santa Maria, Rio Grande do Sul, Brazil, 2019 


\section{RESULTS}

\section{Participant characterization}

Fifty-two nursing professionals participated in the investigation, 30 from the surgical clinic and 22 from the medical clinic. Of the total participants, 13 were nurses, 32 were nursing technicians and seven were nursing assistants.

As for participation by shift and unit, in the first meeting/panel held at the surgical clinic, eight professionals were present in the morning, seven in the afternoon and eight at night. At the medical clinic, seven participated in the morning, six in the afternoon and six at night. Participation in the first meeting/panel totaled 41 professionals; the other 11 were not present due to work demand during the data collection period and changes in work schedule.

In the second meeting/panel, at the surgical clinic, seven professionals were present in the morning, eight in the afternoon, and six at night. At the medical clinic, six participated in the morning, six in the afternoon, and six at night. Soon, there were 38 participants in the second meeting/brainstorming panel. The remaining 14 participants were not present at this meeting due to work demand and/ or changes in work schedule, but participated in the first meeting.

As for sex, 47 were women and five men. In relation to age, 28 were up to 40 years old and 24 were between 41 and 60 years old. Regarding marital status, 13 reported being single; 27 reported being married; and 12 were included in others (common-law marriage, divorced, widowed). As for length of training, 40 had up to 20 years of training; and 12 had between 21 and 45 years. As for length working at the institution, 42 worked for less than 20 years; 23 worked in a period from six months to 10 years; 19 worked from 11 to 20 years; eight worked in a period from 21 to 30 years; one worked between 31 and 40 years; and one worked between 41 and 50 years.

\section{Care Facilitator Cart refining requirements}

From the observation of practices, it was possible to know their work dynamics aiming to identify possible weaknesses.

It is routine for nursing professionals to use plastic bags glued with masking tape or micropore tape on the sides of the carts. They mix infectious and recyclable waste, expose secretion odors [bloody, purulent, serous], circulate with the bag open, sometimes saturated with the amount of waste. (SCO - 08/17/2016, from 02:46 p.m. to 04:30 p.m.)

The units have carts without waste bins so professionals improvise plastic garbage bags glued with adhesive tape to discard all the waste used in the work shift [infectious and recyclable together]. (SCO/MCO - 10/05/2016, from 09:15 a.m. to 11:00 a.m.)

During brainstorming, it was possible to problematize the viability of bins as well as its size, location, and general features. Thus, $58 \%$ of professionals requested bins; $100 \%$ requested removable bins; $90 \%$ requested a sensor for opening; and $100 \%$ requested lids identified with the type of waste.

Separate waste and with a lid, facilitating segregation and preventing circulation of bad smells. (NP 13)
Attached bins and with opening device that avoids the professional's touch. It has the benefit of having a hand access to the bins, which at the same time, prevents contamination. (NP 15)

[...] providing a suitable place for immediate material disposal such as common, recyclable, infectious, disposable waste, in addition to making the material available "by hand" and avoiding further displacement from the unit. (NP 18)

The participants questioned bascule drawers as to their need, dimension, and purpose. Representatively, $65 \%$ of the participants did not consider this model of drawer viable. In contrast, the possibility of using side drawers (19\%) emerged; however, $81 \%$ of the participants opposed the idea. This culminated in a new discussion, with the group's suggestion and $100 \%$ appreciation for the inclusion of a horizontal drawer with a slide; and $81 \%$ validated the horizontal drawer's location on the lower floor, closed and with a side sliding door. Instituting this feature will allow professionals:

During a sacral pressure injury dressing, the nurse realizes the need for another cover. So, with the procedure gloves on, she goes to the nursing station to pick up the material. It should be noted that wearing gloves, the professional touched the cabinet door, the container that stored the cover and later returns to the nursing ward to continue the procedure without changing the gloves. (SCO - 06/11/2016, from 10:00 a.m. to 02:00 p.m.)

[...] greater agility for taking all the basic and essential materials for our work. (NP 08)

[...] placing necessary materials to assist patients, without leaving on the benches or even the patient's bed. (NP 19)

Another element evaluated during brainstorming concerns the number of floors and features. All professionals agreed on keeping the prototype with two floors below, closed and with a sliding door, aiming to restrict access of the clothes used with patients in inpatient units.

Accompanying patients of beds who are in contact isolation by multidrug-resistant microorganisms leave the rooms [without knowing if they have hand hygiene]; handle the clothes of the strollers that are standing in the corridors; take them into the room and after a certain period they return [as if the size of the pajamas was small or an extra piece was taken]; they go to the cart and return the clothes [which have already entered the isolation] together with the others [until then cleaned]. The nursing professional [who is in another ward providing care] returns to the place, handles the cart, does not notice what has happened, and may generate crosstransmission of microorganisms when offering the same clothes to another patient. (SCO - 08/17/2016, from 02:46 p.m. to 04:30 p.m.)

Aspects referring to control and prevention were mentioned, with a view to adding resources that would strengthen safe nursing care. Addition of material collector was brought by all professionals; $96 \%$ suggested alcohol gel dispensers; and all of them suggested adding attached-micropore support.

Professionals cut micropore tapes before finishing the procedure [dressing], fix them on tables [used for food meals] at the bedside/ 
or on the surface of the cart before sticking on patients. (SCO 11/23/2016, from 09:45 a.m. to 11:10 a.m.)

After performing procedures with the use of sharps, they travel to the nursing station with these and other materials on trays for waste disposal. (SCO - 08/19/2016, from 02:10 p.m. to 04:40 p.m.)

Also, it was discussed about the features of the CFC surface, where all participants suggested raised edges of the surface and $94 \%$ requested a retractable accessory table.

[...] to arrange all my material on that surface instead of using the patient's feeding table, or even his bed. This will prevent the transmission of bacteria by cross-transmission. (NP 11)

[...] avoiding the multiple use of the wards 'tables as the table to aid patients' feeding, which is often used for a dressing or to support the basin to perform bed bath. (NP 15)

To perform a dressing, the nursing technician has the clamps and gases under the table designed to assist the patient's food meal. During the procedure, he allocates the saline and micropore beside the patient on the bed. (MCO - 09/16/2016, from 10:00 a.m. to 12:30 p.m.)

Discussions emerged about the sounds produced by carts available on the market. Thus, it was suggested by $100 \%$ of professionals to insert silicone wheels and locks on the four wheels. According to the participants, this inclusion is justified as a preventive strategy to prevent the prototype from moving during procedures and not releasing noise when traveling.

The unit has carts with a simple structure, with two floors, made of stainless steel, with wheels made of material that generates noise [even at night], while traveling. (SCO - 10/05/2016, from 09:15 a.m. to $11: 00$ a.m.)

The wheels have to be siliconized, because at night the unit's cart makes a lot of noise. (NP 30)

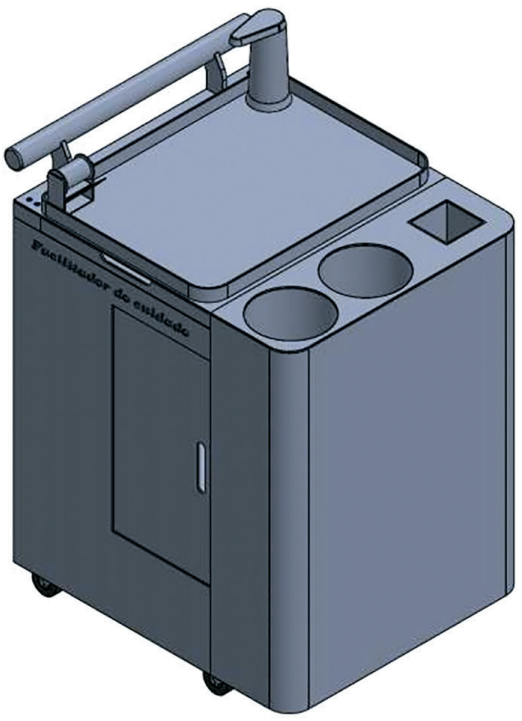

Figure 2 - Final model of the Care Facilitator Cart, Santa Maria, Rio Grande do Sul, Brazil, 2019
After collective element building, the final design was carried out and, subsequently, the materialization of the CFC (Figure 2).

\section{DISCUSSION}

Participants suggested inserting a product to dispose of waste (bins and material collector) in the product, in order to facilitate transportation and reduce the risk of accidents while traveling to the nursing station. Occupational exposure to potentially contaminated biological material is still a worrying factor among nursing professionals in hospitals ${ }^{(10)}$. It is worth considering that occupational accident is an event that occurs during the exercise of the profession, which consists of bodily injury or functional disturbance, reflecting the absence or reduction of work capacity, whether permanent, temporary or even causing death ${ }^{(10-11)}$

Segregation of waste is an indispensable step to guarantee accomplishment of the objectives of an efficient handling system, which consists of separating or selecting them appropriately. Segregation must be carried out at the source of generation according to physical, chemical, biological features, their physical state and the risks involved ${ }^{(12)}$. Disposal must include using plastic bag, which must be supported by acrylic, plastic, metal or other resistant material ${ }^{(13)}$. Such features were used in the product developed.

The inclusion of a large drawer, with large dimensions, located in the lower portion of the CFC, was requested in order to store medium and large materials. This suggestion was taken up in all meetings and was appreciated by all participants. During the observations, it was suggested to include a new drawer with dividers for storing small materials (materials for venipuncture, alcohol sachets, cotton, gauze, alcoholic chlorhexidine, among other materials).

Another element considered was the floors. Considering the work dynamics reported by them and associated with the observations, it was suggested to insert a floor at the bottom of the CFC, as opposed to the guiding design. As a specific feature, a sliding door to the right with manually opened have been included.

Microbial contamination of surfaces was a highlight during the CFC building. This concern by the participants encouraged the inclusion of an alcohol gel dispenser to minimize damage and prevent infections. The microorganisms in the hands of health professionals need to be eliminated and/or reduced, since hand hygiene ends up being neglected in daily work. Although nurses recognize this need as fundamental, in daily reality, what is verified is a deficient hand hygiene practice while providing health care, deficient in technique and adherence to it ${ }^{(14-15)}$.

During collective discussions, the need for an accessory table at the CFC was identified. Accessory table was requested to replace the use of the table available in the room to feed patients and perform procedures. Accessory table is characteristic for its retractable mobility, with a view to providing professionals with greater working space for the disposal of materials and instruments used in their daily work. It is established that such tables are smooth, waterproof, washable and free of roughness that can affect the quality of hygiene and become sources of contamination $^{(16)}$ 
The silicone wheel was an element that, initially, was already composing the guiding design of the CFC and which was accepted by the participants. Sound noise was a daily situation mentioned during data collection, at which point the participants reflected on the possibility of reducing this aggressive agent. Noise is considered a physical agent, comprised of energy in which the worker is also exposed ${ }^{(17)}$. It is noteworthy that it is established by NBR 12809, which establishes that, regarding collection of waste generated by health services, transportation must be carried out without noise ${ }^{(18)}$. This consideration also meets the silicone component established for CFC casters/wheels ${ }^{(19)}$.

It is proposed to reflect on the succession of repercussions that may occur if professionals postpone the disposal of sharps for the performance of a second activity. During displacement in the corridor, sometimes in the observational records, situations were identified that could potentiate occupational accidents: interruptions in the displacement of professionals due to requests from more than one companion of different patients. This fact is associated with the possible inattention in handling work materials, resulting from the professional's physical tiredness, which indicates that the context experienced by nursing professionals also directly interferes in their practice.

Therefore, having specific devices to dispose of infectious and sharps residues with nursing professionals in their daily care provides opportunities to reduce rates of occupational accidents, contamination and the spread of microorganisms. This occurs as the CFC proposes to dispose of waste at the time of its production, at the bedside of patients, separately and with lid opening by a sensor. It is worth considering that identifying professionals with a high workload is also a preventive measure for accidents related to biological, ergonomic, physical or chemical risks ${ }^{(20)}$. Through the CFC, it is proposed to provide easy access to alcohol gel for hand hygiene; the reduction in the use of a food meal table; and the reduction in the availability of materials in common use on beds with patients. Thus, meeting the need to intensify practices that promote agility and encourage hand hygiene, another plausible contribution refers to the probable reduction in daily rework, as the CFC provides a specific place to store the materials most used by professional nurses in carrying out care procedures.

In relation to analysis of the results obtained in this research, it is clear that, in the daily care of both units observed, patients' beds are sometimes used to deposit trays; and these favors contact with sheets contaminated by microorganisms and/or bloody waste. In addition, professionals use the same tray to move medications to more than one patient; and, if it is disposed of in each bed, microorganism transmission is favored.

From the premises presented, it is necessary to encourage nursing professionals to take over the position of leading actors in idealizing the technological product, which enriched the conduction of this study. The innovative act of instigating and enabling target audience participation in a technological product strengthens the characteristics that make up the final model of the CFC. After all, it is known that in the course of professional practice, nursing constantly identifies demands that require an inventive attitude to meet inpatients.

Considering the infinitude of knowledge, there is a need for further studies that deal with the insertion of this technological product in the daily routine of hospital nursing care so that assessment and validation is made possible both by the target audience to which it will be submitted and by expert judges in the field. Therefore, the aim is to make it possible to verify the impact of the CFC in relation to practical use.

\section{Study limitations}

The investigation initially dealt with a technological product building. But validity of this invention by experts is necessary, mainly assessment by the target audience in hospitals.

\section{Contributions to nursing}

It is considered an achievement for nursing to build a product idealized by nurses, which included multidisciplinary and horizontal work with different areas of knowledge such as nursing, technology in mechanical manufacturing, information systems and electrical engineering. Thus, the research reflected in a significant achievement for building a knowledge in nursing, which still builds incipient steps in patenting technological products.

The inventive act of building this technological product culminated in the initiation of patenting, which represents a significant achievement for nursing. Constructing and patenting technologies is still an incipient event for the course. The product technology has a patent filed with the Brazilian National Institute of Industrial Property (Instituto Nacional da Propriedade Industrial, abbreviated INPI), under n BR102017026237-5 on 12/05/2017.

\section{FINAL CONSIDERATIONS}

Through this research, it was possible to collectively build the necessary components for the CFC, guided by the BMC methodology.

The CFC understands an opportunity to establish itself as an ally in promoting a safer and more pleasant environment for nursing professionals and inpatients. As for its contributions, the CFC has the possibility of being an innovative instrument combined with safe hospital care. The CFC makes it possible to reduce damages related to patient care as well as exposure of professionals to biological and physical agents, minimizing the risks related to occupational accidents and occupational diseases, among other aspects. It is noteworthy that, even though the study is being developed in specific hospital units, innovative technology can be successfully implemented in other contexts/ sectors, for instance, in Primary Health Care, in Emergency Care Units, in Joint Accommodations, among others.

It is expected that the CFC will contribute to reducing (re) work in the nursing work routine, through agile access to the materials most used in care. Promoting safe disposal devices for professionals can prevent and/or reduce occupational accidents. Correct disposal of waste will contribute to the spread of a daily practice with responsibility towards sustainability. However, no technology alone promotes, prevents or restores health and/ or reduces indicators related to NI. Also, there is a need for commitment, technical and scientific knowledge, ethics and 
seriousness of professionals in providing care. To that end, the CFC building process was presented as a guiding proposition for further studies and growth in nursing.

\section{FUNDING}

This research was funded by Fundo de Incentivo à Inovação Tecnológica da Universidade Federal de Santa Maria (FIT-UFSM, freely translated as Technological Innovation Incentive Fund of Universidade Federal de Santa Maria).

\section{ACKNOWLEDGMENT}

We would like to thank the Coordination for the Improvement of Higher Education Personnel (Coordenação de Aperfeiçoamento de Pessoal de Nível Superior, abbreviated CAPES).

\section{REFERENCES}

1. Rede Brasileira de Enfermagem e Segurança do Paciente-REBRAENSP. Estratégias para a Segurança do Paciente. Manual para Profissionais da Saúde [Internet]. Porto Alegre: EdiPUCRS. 2013 [cited 2019 Apr 05]. Available from: https://www.rebraensp.com.br/images/publicacoes/ manual_seguranca_paciente.pdf

2. Silva AMB, Andrade D, Wysocki AD, Nicolussi AC, Haas VJ, Miranzi MAS. Conhecimento sobre prevenção e controle de infecção relacionada à assistência à saúde: contexto hospitalar. Rev Rene. 2017;18(3):353-60. doi: 10.15253/2175-6783.2017000300010

3. Soares MI, Camelo SHH, Resck ZMR, Terra FS. Nurses' managerial knowledge in the hospital setting. Rev Bras Enferm. 2016;69(4):676-683. doi: 10.1590/0034-7167.2016690409i

4. Menegueti MG, Canini SRMS, Bellissimo-Rodrigues F, Laus AM. Avaliação dos Programas de Controle de Infecção Hospitalar em serviços de saúde. Rev Latino-Am Enfermagem. 2015;23(1):98-105. doi: 10.1590/0104-1169.0113.2530

5. Nietsche EA, Lima MGR, Rodrigues MGS, Teixeira JN, Oliveira BNB, Motta CA, et al. Tecnologias inovadoras do cuidado em enfermagem. Rev Enferm UFSM. 2012;S.I.2(1):182-9. doi: 10.5902/217976923591

6. Salbego C, Nietsche EA, Teixeira E, Girardon-Perlini NMO, Wild CF, Ilha S. Care-educational technologies: an emerging concept of the praxis of nurses in a hospital context. Rev Bras Enferm. 2018;71(Suppl-6):2666-74. doi: 10.1590/0034-7167-2017-0753

7. Osterwalder A, Pigneur Y. Business model generation: inovação em modelos de negócio. Rio de Janeiro: Alta books, 2011 . p.278 p.

8. Cassenote L, Nietsche EA, Salbego C, Brasil MAB, Ramos TK. Business Model Canvas: possibilidade metodológica para o desenvolvimento de tenologias em enfermagem. I. In: Elizabeth Teixeira. (Org.). Desenvolvimento de Tecnologias Cuidativo-Educacionais: volume 2. Porto Alegre: Moriá, 2019. p. 63-78.

9. Minicucci A. Técnicas do trabalho de grupo. 3 ed. São Paulo: Atlas, 2001.

10. Negrinho NBS, Malaguti-Toffano SE, Reis RK, Pereira FMV, Gir E. Factors associated with occupational exposure to biological material among nursing professionals. Rev Bras Enferm. 2017;70(1):126-310. doi:10.1590/0034-7167-2016-0472

11. Valim MD, Marziale MHP. Avaliação da exposição ocupacional a material biológico em serviços de saúde. Texto Contexto Enferm. 2011;20(spe):138-46. doi: 10.1590/S0104-07072011000500018

12. Agência Nacional de Vigilância Sanitária-Anvisa (BR). Resolução da diretoria colegiada - RDC n 222 , de 28 de março de 2018 . Regulamenta as Boas Práticas de Gerenciamento dos Resíduos de Serviços de Saúde e dá outras providências [Internet]. Publicada no DOU n 61 , de 29 de março de 2018 [cited 2019 Apr 19]. Available from: http://portal.anvisa.gov.br/documents/10181/3427425/RDC_222_2018_.pdf/ c5d3081d-b331-4626-8448- c9aa426ec410

13. Ministério do Trabalho e Emprego (BR). Portaria n 485, de 11 de novembro de 2005 [Internet]. 2005 [cited 2019 Apr 17]. Available from: http://www.trabalho.gov.br/images/Documentos/SST/NR/NR32.pdf

14. Graveto JMGN, Rebola R, Fernandes E, Costa PS. Hand hygiene: nurses' adherence after training. Rev Bras Enferm. 2018;71(3):1189-93. doi: 10.1590/0034-7167-2017-0239

15. Graziano UM, Graziano KU, Pinto FMG, Bruna CQM, Queiroz RQ, Lascala CA. Eficácia da desinfecção com álcool 70\% (p/v) de superfícies contaminadas sem limpeza prévia. Rev Latino-Am Enfermagem [Internet]. 2013 [cited 2019 Apr 25];21 (2). Available from: http://www.scielo.br/pdf/ rlae/v19n3/pt_15.pdf

16. Associação Brasileira de Normas Técnicas. NBR-9190: Dispõe sobre Regulamento Técnico de Boas Práticas para Serviços de Alimentação. ABNT, 2004. Available from: http://portal.anvisa.gov.br/documents/33916/388704/RESOLU\%25C3\%2587\%25C3\%2 830

17. Ministério do Trabalho e Emprego (BR). Portaria no 25, de 29 de dezembro de 1994 [Internet]. Altera o texto da Norma Regulamentadora $n^{\circ}$ 9 - Riscos Ambientais. Diário Oficial da República Federativa do Brasil, Brasília (DF); 1994. [cited 2019 Apr 17]. Available from: http://www. mte.gov.br/legislacao/normas_regulamentadoras/nr_09_at.pdf

18. Associação Brasileira de Normas Técnicas (BR). NBR-12809: Manuseio de resíduos de serviços de saúde - procedimento. ABNT [Internet]. Jan., 1993. [cited 2019 Apr 17]. Available from: https://www.abntcatalogo.com.br/norma.aspx?ID=58155

19. Associação Bra1 sileira de Normas Técnicas (BR). NBR-9190: Sacos plásticos para acondicionamento de lixo. ABNT[Internet]. Jan., 1993. [cited 2019 Apr 17]. Available from: https://www.abntcatalogo.com.br/norma.aspx?ID=80044

20. Gomes AGM, Sabino TDAC, Negreiros RVD. Acidentes de trabalho com materiais biológicos entre profissionais de enfermagem: uma revisão integrativa. Rev Univ Vale Rio Verde. 2016;14(2):1119-27. doi: 10.5892/ruvrd.v14i2.2697 